\title{
PERSEPSI, PEMAHAMAN DAN TINGKAT PENERAPAN SISTEM PERTANIAN ORGANIK OLEH PETANI DALAM BUDIDAYA PADI SAWAH DI SUMATERA BARAT
}

\section{PERCEPTION, UNDERSTANDING AND LEVEL OF THE IMPLEMENTATION OF ORGANIC AGRICULTURAL SYSTEMS BY FARMERS IN WEST SUMATERA PADDY CULTURE}

\author{
Rifda Roswita ${ }^{1}$ dan Eva Riza ${ }^{2}$ \\ ${ }^{1,2}$ Balai Pengkajian Teknologi Pertanian (BPTP) Balitbangtan Sumatera Barat, Jalan Raya Padang \\ Solok Km. 40, Sukarami Kecamatan Gunung Talang Kabupaten Solok, \\ Telepon 0755-31122, Faksimile 0755-31138 \\ Email: rifda1963@gmail.com dan evariza66@gmail.com
}

Naskah Masuk: 06-05-2019

Naskah Diterima: 18-05-2019

Naskah Disetujui: 11-06-2019

\begin{abstract}
The Government of West Sumatra has gradually encouraged the development of organic agriculture, both before and after the organic village program was launched by the Ministry of Agriculture. This study aims to determine: (1) farmers 'perceptions of organic farming systems, (2) farmers' understanding of organic farming systems (3) and the level of application of organic farming systems. The assessment was carried out in March - July 2017 in 3 (three) districts in West Sumatra, namely districts that implemented organic village programs in 2016 and which developed organics through programs before 2016. In each district, one executive group of farmers was selected as an event organic village program in 2016 (in this study it is referred to as a new organic village) and one farmer group that implements organic programs before 2016 (in this study it is referred to as an old organic village). Selected districts are Padang Pariaman, Solok and Limapuluh Kota Regencies. Sampling is done by purposive sampling system. Primary data collection is done by Focus Group Discussion and individual interviews. The data collected are farmers' internal characteristics, farmers' perceptions of organic farming, farmers' understanding of organic farming systems, and the level of application of farmers to organic farming systems. Data were analyzed descriptively and statistically by testing the paired samples T-Test and Mann Whitney difference test to compare between farmers implementing organic village programs and non organic village programs. The results showed that (1) farmers 'perceptions of the nature of the innovation of the organic farming system as a whole, approached a score of 4, namely lower costs, higher production, more profitable, according to farmers' needs, easy to implement, easy to try, and easily observed results. (2) farmers' understanding of the overall components of the organic farming system is high, with a value of 78.55. While the 5 highest understanding variables of farmers are harvest and post-harvest handling and land management and land fertility. The understanding of farmers that still needs to be improved is the understanding of farmers on the conversion period, where some farmers are not very aware of the objectives, and the duration of land conversion even though it has been implemented, (3) the level of application of organic farming system components to organic village farmers is lower (73, 93\%) than old organic village farmers (93.21\%).
\end{abstract}

Keywords: organic farming, perception, understanding, application

\section{ABSTRAK}

Pemerintah Sumatera Barat secara bertahap telah mendorong pengembangan pertanian organik, baik sebelum maupun sesudah program desa organik diluncurkan oleh Kementerian Pertanian. Pengkajian ini bertujuan untuk mengetahui: (1) persepsi petani terhadap sistem pertanian organik, (2) pemahaman petani terhadap sistem pertanian organik (3) dan tingkat penerapan sistem pertanian organik. Pengkajian dilaksanakan pada bulan Maret - Juli 2017 pada 3 (tiga) kabupaten di Sumatera Barat, yaitu kabupaten 
yang melaksanakan program desa organik pada tahun 2016 dan yang mengembangkan organik melalui program sebelum tahun 2016. Pada masing-masing kabupaten dipilih secara acara satu kelompok tani pelaksana program desa organik tahun 2016 (dalam pengkajian ini disebut sebagai desa organik baru) dan satu kelompok tani yang melaksanakan program organik sebelum tahun 2016 (dalam pengkajian ini disebut sebagai desa organik lama). Kabupaten terpilih adalah Kabupaten Padang Pariaman, Solok dan Limapuluh Kota. Pengambilan sampel dilakukan dengan sistim purpossive sampling. Pengumpulan data primer dilakukan dengan Focus Group Discussion dan wawancara perorangan. Data yang dikumpulkan adalah karakteristik internal petani, persepsi petani terhadap pertanian organik, pemahaman petani terhadap sistem pertanian organik, dan tingkat penerapan petani terhadap sistem pertanian organik. Data dianalisis secara deskriptif dan stastistik dengan uji paired samples T-Test uji beda dan Mann Whitney untuk membandingkan antara petani pelaksana program desa organik dan non program desa organik. Hasil penelitian menujukkan bahwa (1) persepsi petani terhadap sifat inovasi sistem pertanian organik secara keseluruhan, mendekati skor 4, yaitu biaya lebih murah, lebih tinggi produksinya, lebih menguntungkan, sesuai dengan kebutuhan petani, mudah dilaksanakan, mudah dicobakan, dan mudah diamati hasilnya, (2) pemahamanan petani terhadap keseluruhan komponen sistem pertanian organik tergolong tinggi yaitu dengan nilai 78,55. Sedangkan dari 5 variabel pemahaman petani paling tinggi adalah penanganan panen dan pasca panen dan pengelolaan lahan dan kesuburan lahan. Pemahaman petani yang masih perlu ditingkatkn adalah pemahaman petani terhadap masa konversi, dimana sebagian petani belum begitu paham terhadap tujuan, dan lama masa koversi lahan walaupun telah menerapkannya, (3) tingkat penerapan komponen teknologi sistem pertanian organik pada petani desa organik lebih rendah $(73,93 \%)$ dari pada petani desa organik lama $(93,21 \%)$.

Kata Kunci: pertanian organik, persepsi, pemahaman, penerapan

\section{PENDAHULUAN}

Pertanian organik merupakan salah satu alternatif untuk memperbaiki kerusakan lahan dan mencegah pencemaran produk pertanian akibat dari penggunaan bahan-bahan kimia dalam proses budidaya pertanian. Hal itu dikarenakan pertanian organik menggunakan bahan-bahan organik dalam proses budidaya yang aman bagi kesehatan dan lingkungan (Miharwansyah, 2015).

Pertanian organik terlahir karena adanya protes dari kunsumen akan banyaknya residu bahan kimia beracun pada produk pertanian, adanya kesadaran masyarakat mengenai bertani yang ramah lingkungan, serta adanya ketertarikan produsen untuk berbisnis produk pertanian organik, karena harganya lebih mahal dari pada produk konvensional (Kardinan, 2016).

Pertanian organik merupakan sistem pertanian yang mulai banyak diterapkan oleh para petani. Pemerintah pun berperan serta dalam peningkatan penerapan sistem pertanian padi organik. Berbagai program telah dilakukan untuk meningkatkan produksi padi, namun peningkatan produksi padi yang dijalankan kurang memperhatikan dampak pada lingkungan. Beberapa penyebab kerusakan lingkungan adalah dengan memberikan pupuk kimia dan pestisida pada tanaman, dua hal tersebut dapat mempengaruhi penurunan kondisi kesuburan lahan, kerusakan lingkungan 
perairan serta produk yang dihasilkan kurang sehat (Agung, 2017).

$$
\text { Untuk menanggulangi }
$$

permasalahan tersebut muncul alternatif untuk bertani menggunakan cara yang lebih ramah lingkungan, salah satunya adalah melalui pertanian organik. Dari beberapa literatur mengungkapkan bahwa pada awal-awal tahun dalam mengusahakan padi organik mengalami penurunan produksi, akan tetapi setelah berjalan stabil pada tahun-tahun berikutnya hasil produksi dapat meningkat bahkan lebih tinggi dibandingkan dengan pertanian konvensional kegiatan pengembangan pertanian organik di Sumatera Barat.

Sistem Pertanian organik memang tidak secara mudah diaplikasikan oleh petani, saat ini masih banyak masalah yang muncul baik dari segi petani maupun pemerintah. Mulai dari kurangnya pelatihan bagi petani tentang sistem pertanian organik sampai dengan akses pasar yang masih sulit terjangkau dan bahkan tidak ada. Belum adanya jalur distribusi yang jelas untuk menampung produk organik yang dihasilkan. Hal ini juga disebabkan kurangnya sosialisasi kepada konsumen dan masyarakat tentang keberadaan produk organik tersebut.
Sehubungan dengan itu pemerintah Provinsi Sumatera Barat secara bertahap mengembangkan pertanian organik. Pemda Sumatera Barat juga telah mendirikan lembaga Sertifikasi Organik (LSO) pada tahun 2007 untuk membantu petani dalam melakukan sertifikasi produk pertanian organik yang mereka hasilkan. Pada tahun 2016, Dinas Pertanian Provinsi Sumatera Barat melalui bantuan dana dari Kementerian Pertanian melaksanakan program desa organik yang tersebar pada 9 (sembilan) kabupaten/kota di Sumatera Barat dengan luas masing-masing 20 ha. Lokasi pengembangan desa padi organik tersebut adalah Kabupaten Tanah Datar, Solok Selatan, Lima Puluh Kota, Pesisir Selatan, Padang Pariaman, Agam, Pasaman, Dharmasraya dan Kota Solok. Sebelumnya Sumatera Barat telah memiliki lahan padi organik yang telah disertifikasi seluas 96.991 hektar dengan 17 kelompok tani (Tamela, 2017).

Secara umum beberapa persepsi petani terhadap sistim pertanian organik, dengan menggunakan bahan organik sebagai sarana produksi dalam berusahatani, maka secara perlahan dapat memperbaiki kondisi lahan yang 
telah mengalami degradasi untuk berproduksi. Selain dari itu persepsi petani bahwa pertanian organik yang ramah lingkungan merupakan salah satu alternatif untuk mengurangi ketergantungan terhadap penggunaan sarana produksi sintetis. Pemanfaatan bahan organik merupakan contoh nyata keberhasilan penerapan sistim pertanian yang selaras dengan alam (Basri, 2016)

Dari permasalahan tersebut dapat dirumuskan bahwa tujuan dari pengkajian ini adalah untuk mengetahui bagaimana persepsi petani terhadap sistem pertanian organik, pemahaman petani terhadap sistem pertanian organik, dan tingkat penerapan petani terhadap inovasi teknologi pertanian organik di Sumatera Barat.

\section{METODOLOGI}

Pengkajian dilaksanakan pada tiga kabupaten di Sumatera Barat pada bulan Maret sampai dengan Juni 2017. Lokasi dipilih secara sengaja (purposive) yaitu kabupaten yang melaksanakan program desa organik pada tahun 2016 dan yang mengembangkan pertanian organik melalui program sebelum tahun 2016. Kabupaten terpilih adalah Kabupaten Padang Pariaman, Solok dan Limapuluh Kota. Pada masing-masing kabupaten dipilih secara acara satu kelompok tani pelaksana program desa organik tahun 2016 (dalam pengkajian ini disebut sebagai desa organik baru) dan satu kelompok tani yang melaksanakan program organik sebelum tahun 2016 (dalam pengkajian ini disebut sebagai desa organik lama). Responden dipilih secara acak dengan jumlah 10-15 orang per kelompok tani.

Pengkajian adalah pengkajian survey. Teknik pengumpulan data dilakukan dengan Focus Group Discussion dan observasi lapangan dan dilanjutkan dengan wawancara perorangan dengan responden menggunakan kuesioner atau daftar pertanyaan. Pengukuran persepsi menggunakan skala likert (1-4) sedangkan pengukuran tingkat pemahaman dan tingkat adopsi menggunakan beberapa pertanyaan terbuka yang diberi nilai antara 0-100.

Persepsi petani terhadap sistem pertanian organik meliputi: 1) persepsi terhadap biaya, 2) persepsi terhadap tenaga kerja, 3) persepsi terhadap produksi, 4) persepsi terhadap keuntungan, 5) persepsi terhadap kesesuaian sistem pertanian organik dengan kebutuhan petani (kompatibilitas), 6) persepsi terhadap 
kerumitan sistem pertanian organik (kompleksitas), 7) persepsi terhadap kemudahan untuk dicoba (triabilitas) dan 8) persepsi terhadap kemudahan untuk diamati hasilnya (observabilitas).

Data dikumpulkan terlebih dahulu ditabulasi kemudian dianalisis secara deskriptif dan stastistik dengan uji paired samples T-Test dan uji beda Mann Whitney untuk membandingkan antara kelompok tani desa organik lama dan kelompok tani desa organik baru (Suliyanto, 2014).

\section{HASIL DAN PEMBAHASAN}

\section{Karakteristik Internal Petani}

Dalam pengembangan padi sawah organik sumberdaya lahan dan sumberdaya manusia merupakan komponen penting dalam aktivitas pertanian sehingga perlu diketahui karakteristiknya agar dapat dimanfaatkan secara optimal (Rusiyah, 2012). Karakteristik petani yang diduga mempengaruhi persepsi terhadap sistem pertanian organik adalah umur, pendidikan, pengalaman bertani, jumlah tanggungan keluarga, luas penguasaan lahan, kepemilikan ternak, serta lama memperoleh pengetahuan tentang sistem pertanian organik.
Karakteristik internal petani dapat dilihat pada Tabel 1.

Tabel 1. Karakteristik internal petani

\begin{tabular}{|c|c|c|c|c|}
\hline \multirow{2}{*}{$\begin{array}{l}\text { Variabel } \\
\text { Karakteristik } \\
\text { Internal } \\
\text { responden }\end{array}$} & \multicolumn{4}{|c|}{ Karakteristik responden (rata-rata) } \\
\hline & $\begin{array}{l}\text { Desa } \\
\text { Organik } \\
\text { baru }\end{array}$ & $\begin{array}{l}\text { Desa } \\
\text { Organik } \\
\text { lama }\end{array}$ & Total & Nilai $P$ \\
\hline Umur (tahun) & $\begin{array}{l}51,83 \\
(30-78)\end{array}$ & $\begin{array}{c}45,03 \\
(19-64)\end{array}$ & $\begin{array}{l}8,43 \\
(19- \\
78)\end{array}$ & $0,014^{* *}$ \\
\hline $\begin{array}{l}\text { Pendidikan } \\
\text { (tahun) }\end{array}$ & $\begin{array}{l}8,77 \\
(5-16)\end{array}$ & $\begin{array}{l}9,75 \\
(0-16)\end{array}$ & $\begin{array}{l}9,26 \\
(0- \\
16)\end{array}$ & 0,869 \\
\hline $\begin{array}{l}\text { Pengalaman } \\
\text { bertani organik } \\
\text { (tahun) }\end{array}$ & $\begin{array}{l}4,45 \\
(1-10)\end{array}$ & $\begin{array}{l}5,33 \\
(0,5-11)\end{array}$ & $\begin{array}{l}4,89 \\
(0,5- \\
11)\end{array}$ & $0,001 * *$ \\
\hline $\begin{array}{l}\text { Jumlah } \\
\text { tanggungan } \\
\text { keluarga } \\
\text { (orang/KK) }\end{array}$ & $\begin{array}{l}4,03 \\
(1-9)\end{array}$ & $\begin{array}{l}4,77 \\
(2-10)\end{array}$ & $\begin{array}{l}4,40 \\
(1- \\
10)\end{array}$ & $0,013^{* *}$ \\
\hline Luas & 0,41 & 0,54 & 0,48 & 0,509 \\
\hline $\begin{array}{l}\text { Penguasaan } \\
\text { lahan (ha) }\end{array}$ & $\begin{array}{l}(0,3- \\
1,25)\end{array}$ & $(0,1-3)$ & $\begin{array}{l}(0,03- \\
3)\end{array}$ & \\
\hline $\begin{array}{l}\text { Kepemilikan } \\
\text { ternak sapi } \\
\text { (ekor/KK) }\end{array}$ & $\begin{array}{l}0,87 \\
(0-8)\end{array}$ & $\begin{array}{l}1,05 \\
(0-9)\end{array}$ & $\begin{array}{l}0,96 \\
(0-9)\end{array}$ & 0,265 \\
\hline $\begin{array}{l}\text { Lama } \\
\text { perolehan ilmu } \\
\text { organik (tahun) }\end{array}$ & $\begin{array}{l}4,27 \\
(1-10)\end{array}$ & $\begin{array}{l}5,8 \\
(1-11)\end{array}$ & $\begin{array}{l}5,04 \\
(1- \\
11)\end{array}$ & $0,001^{* *}$ \\
\hline
\end{tabular}

Tabel 1 Menunjukkan bahwa umur petani berkisar antara 19 sampai 78 tahun, rata-rata 48,43 tahun. Umur petani pada kelompok tani desa organik baru lebih tinggi dari pada kelompok tani desa organik lama. Berdasarkan penggolongan umur produktif dan tidak produktif, maka sebagian besar petani responden berada dalam katagori umur produktif, dimana kisaran umur produktif berkisar antara 15- 55 tahun (Rochani, dkk., 2004). Pada umur ini, kemampuan fisik petani sangat 
berpengaruh untuk bekerja secara optimal.

Pendidikan pada kelompoktani desa organik baru lebih rendah dari kelompoktani desa organik lama. Tingkat pendidikan formal petani sangat berpengaruh terhadap kemampuan dalam merespon suatu inovasi. Makin tinggi tingkat pendidikan formal petani, diharapkan makin rasional pola pikir dan daya nalarnya. Dengan pendidikan yang semakin tinggi, maka semakin lebih mudah merubah sikap dan perilaku untuk bertindak lebih rasional (Basri, 2016).

Pengalaman bertani berkisar antara 0,5 sampai 11 tahun, rata-rata 4,89 tahun. Petani pada desa organik baru mempunyai pengalaman bertani organik antara 1-10 tahun atau 4,45 tahun, yang ternyata tidak jauh berbeda dari kelompok tani desa organik lama yang berkisar antara 0,5-11 tahun atau rata-rata 5,33 tahun. Respon, tanggapan dan penerimaan petani terhadap suatu inovasi teknologi bergantung pada pengalaman petani, semakin lama petani dalam berusahatani, maka tingkat respon terhadap suatu teknologi akan semakin tinggi (Nuhung, 2003).
Jumlah tanggungan petani 1-10 orang per KK, rata-rata 4,4 orang/KK. Jumlah tanggungan anggota kelompoktani ratarata 4,03 orang/KK, lebih rendah dari jumlah tanggungan petani pada kelompok tani desa organik lama yang mencapai 4,77 orang/KK.

Luas penguasaan lahan hanya 0,03-3 ha dengan rata-rata $0,48 \mathrm{ha} / \mathrm{KK}$. Rata-rata luas lahan petani pelaksana desa organik baru lebih kecil dari petani desa organik lama yang mencapai 0,54 ha/KK atau 0,1-3 ha/KK

Tidak semua petani organik memiliki ternak sapi. Umumnya petani memiliki ternak antara 0-9 ekor atau rata-rata 0,96 ekor/KK. Jumlah kepemilikan ternak sapi pada petani desa organik baru (rata-rata 0,87 ekor/KK), lebih rendah dari petani pada desa organik lama yang mencapai 0,96 ekor/KK. Ternak sapi merupakan sarana pendukung yang sangat dibutuhkan sebagai penghasil pupuk organik untuk pemenuhan unsur hara tanaman. Sebagaimana dikemukakan oleh Wahyudi dan Sujianto (2014), bahwa penggerak utama dalam penerapan sistem pertanian organik adalah ketersedaiaan sarana pendukung seperti pupuk organik yang mudah diperoleh dan tersedia di lingkungan sekitar. 
Rata-rata lama memperoleh ilmu tentang sistem pertanian organik 5,04 tahun atau berkisar antara 1-11 tahun. Anggota kelompoktani desa organik lama memperoleh ilmu tentang petanian organik lebih dulu dari petani desa organik baru.

Hasil uji beda $\mathrm{t}$ pada Tabel 1 . menunjukkan bahwa karakteristik internal petani pada desa organik baru dan desa organik lama berbeda nyata sampai sangat nyata adalah umur, pengalaman bertani, jumlah tanggungan keluarga dan lama memperoleh ilmu tentang pertanian organik. Menurut Wangke, Olfi dan Suzana (2016), umur muda, pendidikan lebih tinggi, pemilikan lahan yang luas, dan pendapatan yang tinggi cenderung tingkat adopsi inovasi padi sawah organik lebih tinggi.

\section{Persepsi Petani Terhadap Sistem Pertanian Organik}

Hasil penelitian tentang persepsi petani terhadap sistem pertanian organik dapat dilihat pada Tabel 2.

Tabel 2. Persepsi petani terhadap sistem pertanian organik

\begin{tabular}{lcccc}
\hline \multirow{2}{*}{ Sifa Inovasi } & \multicolumn{4}{c}{ Persepsi (rata-rata) } \\
\cline { 2 - 5 } & $\begin{array}{l}\text { Desa } \\
\text { Organik } \\
\text { baru }\end{array}$ & $\begin{array}{l}\text { Desa } \\
\text { Organik } \\
\text { lama }\end{array}$ & Total & $\begin{array}{l}\text { Nilai } \\
\text { P }\end{array}$ \\
\hline Biaya & 3,88 & 3,80 & 3,84 & 0,666 \\
Tenaga kerja & 2,82 & 2,68 & 2,75 & 0,427 \\
Produksi & 3,43 & 3,48 & 3,45 & 0,799
\end{tabular}

\begin{tabular}{lllll}
$\begin{array}{l}\text { Keuntungan } \\
\text { relatif }\end{array}$ & 3,68 & 3,65 & 3,66 & 0,939 \\
Kompatibilitas & 3,85 & 3,83 & 3,83 & 0,763 \\
Kompleksitas & 3,68 & 3,48 & 3,58 & 0,124 \\
Triabilitas & 3,70 & 3,55 & 3,63 & 0,100 \\
Observabilitas & 3,75 & 3,85 & 3,80 & 0,061 \\
Total & 3,60 & 3,54 & 3,57 & \\
\hline
\end{tabular}

Keterangan:

$1=$ tidak tahu

2=lebih mahal/banyak/rendah/tidak sesuai/tidak mudah

$3=$ sama saja/sebagian sesuai/sebagian mudah 4=lebih murah/lebih sedikit/lebih tinggi/lebih menguntungkan/sesuai/semua mudah

$\mathrm{P}=$ probabilitas

Secara keseluruhan, persepsi petani terhadap sifat inovasi sistem pertanian organik mendekati skor 4, dimana inovasi teknologi sistem pertanian organik dianggap mempunyai biaya lebih murah, produksi lebih tinggi, lebih menguntungkan, sesuai dengan kebutuhan petani, mudah dilaksanakan, mudah dicobakan, serta mudah diamati hasilnya. Beras organik dianggap oleh petani lebih berat, rasa nasi lebih manis dan tahan lama. Penerapan sistem pertanian organik menyebabkan berkurangnya serangan OPT karena telah terjadi keseimbangan ekosistem akibat tidak lagi menggunakan pestisida.

Hal tersebut senada dengan yang disampaikan oleh Kustiari (2016) bahwa secara umum persepsi petani terhadap budidaya padi organic: memiliki keunggulan lebih baik dibandingkan teknologi budidaya padi 
secara konvensional seperti keamanan produk, ramah lingkungan, cepat panen, produksi padi dapat maksimal, sebagian besar (50\% dan $41 \%)$ petani memiliki persepsi positif bahwa teknologi budidaya padi organik mudah diaplikasikan dan sesuai dengan kondisi alam dan lingkungan.

Ashari (2016) menyatakan bahwa pertanian organik benar-benar dapat memberikan manfaat dan tidak sulit untuk dipraktikkan. Pertanian organik dapat memperbaiki kesuburan tanah, meningkatkan produktivitas, mengurangi biaya produksi, mempermudah pengolahan tanah, meningkatkan pendapatan, lebih besar mengontrol pekerjaan di sawah, harga jual lebih bagus sehingga keunggulan pertanian mampu menutupi kekurangannya (Siti Wahana, 2018). Hal senada juga disampaikan Asiah (2010), bahwa persepsi petani terhadap padi organik adalah pemasaran cukup mudah, cukup unggul, produktivitas cukup tinggi, dan cukup menguntungkan.

Penilaian terhadap sifat inovasi penting artinya dalam membentuk sikap berkenan atau tidak berkenan terhadap suatu inovasi (Rogers dan Shoemaker, 1971).
Hasil uji beda Mann Whitney pada Tabel 2. menunjukkan bahwa penilaian petani desa organik baru dan petani desa organik lama terhadap sifat inovasi sistem pertanian organik, tidak berbeda nyata dan bernilai positif. Hal ini menunjukkan bahwa petani di Sumbar sama-sama mempunyai persepsi positif terhadap sistem pertanian organik. Menurut Wiratmadja (2017), petani menyatakan bahwa pertanian organik merupakan ide yang bijak, perbuatan yang baik, penting untuk kesehatan manusia dan kelestarian lingungan. Semakin positif sikap petani terhadap pertanian organik maka akan semakin besar mempengaruhi niat petani untuk menggunakan pertanian organik.

\section{Pemahaman Petani Terhadap Sistem Pertanian Organik}

Komponen sistem pertanian organik terdiri dari masa konversi, pengelolaan kontaminasi tanah dan air, pengelolaan lahan dan kesuburan lahan, pemilihan varietas dan perbenihan, pengelolaan gulma dan OPT, serta pengelolaan panen dan pasca panen. Pemahaman petani terhadap komponen sistem pertanian organik tersebut dapat dilihat pada Tabel 3. 
Tabel 3. Pemahaman petani terhadap komponen sistem pertanian organik

\begin{tabular}{|c|c|c|c|c|}
\hline \multirow[b]{2}{*}{$\begin{array}{l}\text { Variabel } \\
\text { Pemahaman }\end{array}$} & \multicolumn{4}{|c|}{ Nilai Pemahaman (rata-rata) } \\
\hline & $\begin{array}{l}\text { Desa } \\
\text { Organik } \\
\text { baru }\end{array}$ & $\begin{array}{l}\text { Desa } \\
\text { Organik } \\
\text { lama }\end{array}$ & Total & $\begin{array}{l}\text { Nilai } \\
\text { P }\end{array}$ \\
\hline $\begin{array}{l}\text { Pemahaman } \\
\text { terhadap masa } \\
\text { konversi }\end{array}$ & 64,28 & 74,98 & 69,63 & $0,000 * *$ \\
\hline $\begin{array}{l}\text { Pemahaman } \\
\text { terhadap } \\
\text { kontaminasi } \\
\text { tanah dan air }\end{array}$ & 70,00 & 75,00 & 72,50 & 0,325 \\
\hline $\begin{array}{l}\text { Pemahaman } \\
\text { terhadap } \\
\text { pengelolaan } \\
\text { lahan dan } \\
\text { kesuburan lahan }\end{array}$ & 77,50 & 85,00 & 81,25 & 0,088 \\
\hline $\begin{array}{l}\text { Pemahaman } \\
\text { terhadap } \\
\text { pengelolaan } \\
\text { gulma dan OPT }\end{array}$ & 78,75 & 82,50 & 80,63 & 0,173 \\
\hline $\begin{array}{l}\text { Pemahaman } \\
\text { terhadap } \\
\text { pengelolaan } \\
\text { panen dan pasca } \\
\text { panen }\end{array}$ & 86,25 & 91,25 & 88,75 & $0,046^{*}$ \\
\hline Total & 75,36 & 81,75 & 78,55 & $0,012^{*}$ \\
\hline
\end{tabular}

Keterangan: sangat rendah (0-20); rendah (21-40); sedang (41-60); tinggi (61-80), sangat tinggi (81-100) $\mathrm{P}=$ probabilitas, ${ }^{* *}=$ berbeda sangat nyata pada $\mathrm{p}=$ 0,01

Data Tabel 3 menunjukkan bahwa nilai pemahamanan petani terhadap keseluruhan komponen sistem pertanian organik tergolong tinggi yaitu dengan nilai 78,55. Sedangkan dari 5 variabel pemahaman petani paling tinggi adalah penanganan panen dan pasca panen serta pengelolaan lahan dan kesuburan lahan. Pemahaman petani yang masih perlu ditingkatkan adalah pemahaman petani terhadap masa konversi, dimana sebagian petani belum begitu paham terhadap masa konversi lahan, tujuan dan manfaat masa konversi walaupun sudah menerapkan.

Pemahaman petani desa organik lama terhadap komponen sisitem pertanian organik lebih tinggai daripada petani desa organik baru. Hasil uji t terlihat pada Tabel 3 bahwa secara keseluruhan pemahaman petani pelaksana desa organik baru terhadap sistem pertanian organik berbeda nyata dengan pemahaman petani desa organik lama.

Per komponen sistem pertanian organik terlihat bahwa pemahaman petani terhadap masa konversi berbeda sangat nyata, demikian juga pemahaman petani terhadap penanganan panen dan pasca panen, sedangkan pemahaman petani terhadap komponen teknologi lainnya tidak berbeda nyata.

\section{Tingkat Penerapan Sistem Pertanian Organik}

Tingkat penerapan sistem pertanian organik terdiri dari: 1) Masa konversi, 2) pengelolaan kontaminasi tanah dan air, 3) pengelolaan lahan dan kesuburan tanah, 4) pemilihan varietas dan perbenihan, 5) pengelolaan gulma, 6) pengelolaan OPT, 7) Penanganan panen dan pasca panen. Hasil penelitian tentang tingkat penerapan sistem pertanian organik dapat dilihat pada Tabel 4. 
Tabel 4. Tingkat penerapan sistem pertanian organik

\begin{tabular}{|c|c|c|c|c|}
\hline \multirow{2}{*}{$\begin{array}{l}\text { Variabel Sistem } \\
\text { Pertanian } \\
\text { Organik }\end{array}$} & \multicolumn{4}{|c|}{ Tingkat Penerapan } \\
\hline & $\begin{array}{l}\text { Desa } \\
\text { Organik } \\
\text { baru }\end{array}$ & $\begin{array}{l}\text { Desa } \\
\text { Organik } \\
\text { lama }\end{array}$ & Total & $\begin{array}{l}\text { Nilai } \\
\text { P }\end{array}$ \\
\hline Masa konversi & 100,00 & 100,00 & 100,00 & 0 \\
\hline $\begin{array}{l}\text { Pengelolaan } \\
\text { kontaminasi } \\
\text { tanah dan air }\end{array}$ & 37,50 & 87,50 & 62,50 & $\begin{array}{l}0,000 \\
* *\end{array}$ \\
\hline $\begin{array}{l}\text { Pengelolaan } \\
\text { lahan dan } \\
\text { kesuburan tanah }\end{array}$ & 90,00 & 97,50 & 93,75 & $\begin{array}{l}0,005 \\
* *\end{array}$ \\
\hline $\begin{array}{l}\text { Pemilihan } \\
\text { varietas dan } \\
\text { perbenihan }\end{array}$ & 37,50 & 77,50 & 57,50 & $\begin{array}{l}0,005 \\
* *\end{array}$ \\
\hline $\begin{array}{l}\text { Pengelolaan } \\
\text { gulma }\end{array}$ & 85,00 & 100,00 & 92,50 & $\begin{array}{l}0,000 \\
* *\end{array}$ \\
\hline Pengelolaan OPT & 97,50 & 100,00 & 98,80 & $\begin{array}{l}0,043 \\
*\end{array}$ \\
\hline $\begin{array}{l}\text { Penanganan } \\
\text { panen dan pasca } \\
\text { panen }\end{array}$ & 70,00 & 90,00 & 80,00 & $\begin{array}{l}0,000 \\
* *\end{array}$ \\
\hline Total & 73,93 & 93,21 & 83,57 & $\begin{array}{l}0,001 \\
* *\end{array}$ \\
\hline
\end{tabular}

Keterangan: sangat rendah (0-20); rendah (21-40); sedang (41-60); tinggi (61-80), sangat tinggi (81-100)

$\mathrm{P}=$ probabilitas,$*=$ berbeda nyata pada $\mathrm{p}=0.01$

$* *$ = berbeda sangat nyata pada $\mathrm{p}=0.05$

Tabel 4 Menunjukkan bahwa tingkat penerapan komponen teknologi sistem pertanian organik pada petani desa organik baru lebih rendah $(73,93 \%)$ dari pada petani desa organik lama (93,21\%), kecuali pada masa konversi, semuanya sudah menerapkan $(100 \%)$. Uji beda menunjukkan bahwa terdapat perbedaan yang sangat nyata antara tingkat penerapan sistem pertanian organik antara petani desa organik baru dan desa organik lama, kecuali penerapan masa konversi yang tidak berbeda. Hal ini disebabkan karena pengalaman petani serta frekuensi penyuluhan yang diikuti oleh petani pelaksana desa organik baru lebih rendah dari pada desa organik lama.

Menurut Charina (2018) bahwa keberhasilan pengembangan pertanian organik akan terwujud ketika ada dukungan dari pemerintah baik dalam bentuk pelatihan, modal produksi serta regulasi masing-masing tingkat Pemerintah Daerah.

\section{KESIMPULAN}

1. Persepsi petani terhadap sifat inovasi sistem pertanian organik secara keseluruhan, mendekati skor 4, yaitu biaya lebih murah, lebih tinggi produksinya, lebih menguntungkan, sesuai dengan kebutuhan petani, mudah dilaksanakan, mudah dicobakan, dan mudah diamati hasilnya.

2. Pemahaman petani terhadap keseluruhan komponen sistem pertanian organik tergolong tinggi yaitu dengan nilai 78,55. Sedangka dari 5 variabel pemahaman petani paling tinggi adalah penanganan panen dan pasca panen serta pengelolaan lahan dan kesuburan lahan. Pemahaman petani yang masih perlu ditingkatkan adalah pemahaman terhadap masa 
konversi, dimana sebagian petani belum begitu paham terhadap tujuan dan lama masa koversi lahan walaupun telah menerapkannya.

3. Tingkat penerapan komponen teknologi sistem pertanian organik pada petani desa organik baru lebih rendah $(73,93 \%)$ dari pada petani desa organik lama $(93,21 \%)$.

\section{REKOMENDASI}

1. Pemilihan lokasi pengembangan pertanian organik harus

\section{DAFTAR PUSTAKA}

A. Charina, R. Andriani BK,. A Hermita Sadeli, Y. Deliana 2018. Faktor-faktor yang Mempengaruhi Petani dalam Menerapkan Standar Operasional Prosedur (SOP) Sistem Pertanian Organik di Kabupaten Bandung Barat Jurnal Penyuluhan, Maret 2018 Vol. 14 No. 1

Agung, F.K., L. Rahayu, Sutrisno, 2017. Persepsi Petani Terhadap Sistem Pertanian Padi Organik Di Kecamatan Bener, Kabupaten Purworejo.

Aninomous,2019. https://www.pioneer.com/web/si te/indonesia/Sistem-

PertanianOrganik-Solusi-bagi-

Kesejahteraan-Petani, di akses tgl 10 Januari 2019

Ashari, J. Sharifuddin, Z.A.Mohammed, R. Terano 2016. Persepsi Petani Terhadap Teknologi Usaha Tani Organik Dan Niat Untuk Mengadopsinya memperhatikan ketersediaan sarana pendukung seperti: ketersediaan ternak.

2. Persepsi petani yang cukup tinggi merupakan modal untuk mengembangkan pertanian organik di Sumatera Barat.

3. Program desa organik harus disertai dengan pembinaan dan pendampingan yang berkelanjutan.

Asiah, N, Hasanuddin T, Suarno, 2010 Sadar, S persepsi Petani Terhadap Padi Organik Di Kecamatan Pagelaran Kabupaten Pringsewu

Basri, H. 2016, Analisis Persepsi Petani Terhadap Pemanfaatan Bokashi Pada Pertanaman Padi Sawah AGRISEP Vol. 15 No. 2 September 2016 Balai Pelatihan Pertanian (BPP) Lampung

Kardinan, A. 2014. Prinsisp-prinsip dan Teknologi Pertanian Organik. IAARD Press. Bogor

Kardinan, A. 2016, Sistem Pertanian Organik, inofice (Indonesia Organic Farming Certification, Lembaga Sertifikasi Pertanian Organik Indonesia.

Kustiari, T. 2016, Tingkat Penerapan Teknologi Budidaya Padi Organik Di Desa Lombok Kulon Kecamatan Wonosari Kabupaten Bondowoso, Prosiding Seminar Nasional ISBN 978-602-60569$2-4$ 
Miharwansyah, N. 2015, Persepsi

Petani Terhadap Prinsip

Pertanian Organik Universitas

Gadjah Mada, 2015

Mayrowani, H. 2012. Pengembangan Pertanian Organik Di Indonesia Forum Penelitian Agro Ekonomi, Volume 30 No. 2, Desember 2012 : 91 - 108

Nuhung, I., A.. 2003. Membangun Pertanian Masa Depan, Suatu Gagasan Pembaharuan. Aneka Ilmu. Semarang.

Rochani, A.Y, Abdullah, Matanubun, $2004 . \quad$ Pengembangan Agropolitan Grime-Sekori. Pusat Penelitian Pemberdayaan Fiskal dan Ekonomi Daerah Universitas Negeri Papua Bekerjasama dengan Pemerintah Kabupaten Jayapura, Jayapura.

Rogers EM, Shoemaker. 1971. Communication of Innovation. A Cross-Cultural Approach. Second Edition. New York: The Free Press.

Roswita, R., N. Hasan, Z. Irfan, Harmaini, Jefry, Yunasri, Evariza. 2017. Kajian Model Desa Organik berbasis PadiTernak di Sumatera Barat. Laporan hasil pengkajian tahun 2017. Balai Pengkajian Teknologi Pertanian Sumatera Barat. 51 hal.

Rusiyah, Widiatmoko. D.S Dan Yunianto T, 2012. Studi Pengembangan Pertanian Padi Sawah Organik Berdasarkan Kesesuaian Lahan Dan Potensi Pupuk Organik Dari Limbah Pertanian Di Kecamatan Temon
Kabupaten Kulon Progo ISSN 0125-1790 MGI Vol. 26, No. 2, September $2012(190-203)$ (C) 2012 Fakultas Geografi UGM.

Siti Wahana, 2018. Pertanian Organik Dalam Persepsi Petani Desa Bantaragung Sebagai Penjaga Kelestarian Kawasan Hutan TNGC, LOGIKA, Desember 2018, XXII (3): 51-57

Suliyanto. 2014. Statistika Non Parametrik Dalam Aplikasi Penelitian Penerbit ANDI Yogyakarta

Tamela, P. 2017. Sumbar Kembangkan Sembilan Desa Pertanian Organik https://sumbar.antaranews.com/b erita/197747/sumbarkembangkan-sembilan-desapertanian-organik diakses 24 Januari 2018

Wahyudi, A., Sujianto. 2014. Pertanian Organik dan Pendapatan Petani dalam Prinsip-prinsip dan Teknologi Pertanian Organik. AARD Press. Bogor.

Wiratmadja, I., N. Nurjanah, dan A. Kurniawati, $2017 \quad$ Model Penerimaan Petani Terhadap Teknologi Sistem Pertanian Organik Di Kabupaten Tasikmalaya Jurnal Manajemen Teknologi, 16(1), 2017,81-91.

Wangke, B. Olfie dan Suzana. 2016. Adopsi Petani terhadap Inovasi Tanaman Padi Sawah Organik di Desa Molopar Tombatu Timur Kab. Minahasa Tenggara. AgriSosioEkonomi Unstrat, ISSN 1907-4298 Vol. 12 Nomor 2, Mei 2016: 143-152. 